\title{
A new record of Lamellibrachia columna (Siboglinidae, Annelida) from cold seeps off New Zealand, and an assessment of its presence in the western Pacific Ocean
}

\author{
Marina F. McCowin ${ }^{1 *}$, Ashley A. Rowden² and Greg W. Rouse
}

\begin{abstract}
Lamellibrachia columna Southward was originally described from hydrothermal vents of the Lau Basin, between Fiji and Tonga. This study utilizes phylogenetic and morphological analyses to confirm the collection of Lamellibrachia columna from cold seeps on the Hikurangi Margin off New Zealand, thereby extending its geographic range southward by approximately $1900 \mathrm{~km}$. We also propose, based on molecular evidence, that specimens previously reported from vents in the Nankai Trough, Japan and seeps off southern and eastern Japan are L. columna. Furthermore, we suggest that Lamellibrachia sagami Kobayashi et al. described from cold seeps off southern and eastern Japan is a junior synonym of Lamellibrachia columna. Our work confirms that L. columna is found at two types of chemosynthetic habitat over a wide geographic range in the western Pacific Ocean.
\end{abstract}

Keywords: Vestimentifera, Deep sea, Pacific Ocean, Phylogeny, Synonymy

\section{Background}

Members of Vestimentifera (originally introduced by Jones (1985), and now one of four informal lineages within Siboglinidae Caullery, 1914 [Hilário et al. 2011; Pleijel et al. 2009]) live in chemosynthetic environments such as hydrothermal vents (Bright and Lallier 2010; Jones 1980; Shank et al. 1998), cold seeps (Bright and Lallier 2010; Levin et al. 2012; Webb 1969), and whale falls (Bright and Lallier 2010; Feldman et al. 1998), where they subsist off endosymbiotic chemoautotrophic bacteria (Bright and Lallier 2010). Lamellibrachia Webb, 1969 is one of the few vestimentiferan genera with a broad geographic and habitat distribution, having been reported from seeps, vents, and whale bones in the $\mathrm{Pa}$ cific, Atlantic, Caribbean, and Gulf of Mexico (Bright and Lallier 2010; Feldman et al. 1998; Kobayashi et al. 2015; Nishijima et al. 2010; Watanabe et al. 2010). Of the nine Lamellibrachia species described to date, Lamellibrachia columna Southward, 1991 was the first

\footnotetext{
* Correspondence: marruda@ucsd.edu

${ }^{1}$ Scripps Institution of Oceanography, University of California San Diego, La Jolla, CA, USA

Full list of author information is available at the end of the article
}

to be described from the southwestern Pacific, at $1870 \mathrm{~m}$ in an area of diffuse venting at the Lau Back-arc Basin (Southward 1991). Since its initial discovery, L. columna has been reported at diffuse vents from the southwestern Pacific back-arc basin at Lau from 1832 to $1914 \mathrm{~m}$ (Black et al. 1997; Kojima et al. 1997, 2001; Southward 1991; Southward et al. 2011) (Fig. 1). To date, Lamellibrachia columna is most easily differentiated from other Lamellibrachia species by its numbers of sheath and branchial lamellae (Southward 1991). Other diagnostic characteristics such as obturaculum dimensions and plaque size are quite variable and overlap with those of other Lamellibrachia species, making DNA data and phylogenetic analyses an important part of the identification process (Kobayashi et al. 2015; McCowin and Rouse 2018; Southward 1991; Southward et al. 2011). The Japanese samples identified as Lamellibrachia sp. L1 and Lamellibrachia sp. L2 (Kojima et al. 2001) were noted as being very close to a published sequence (Black et al. 1997) of Lamellibrachia columna from the type locality, with L2 as the sister taxon to L. columna. Kojima et al. (2001) even noted that "L1 and L2 might be conspecific with L. columna". 


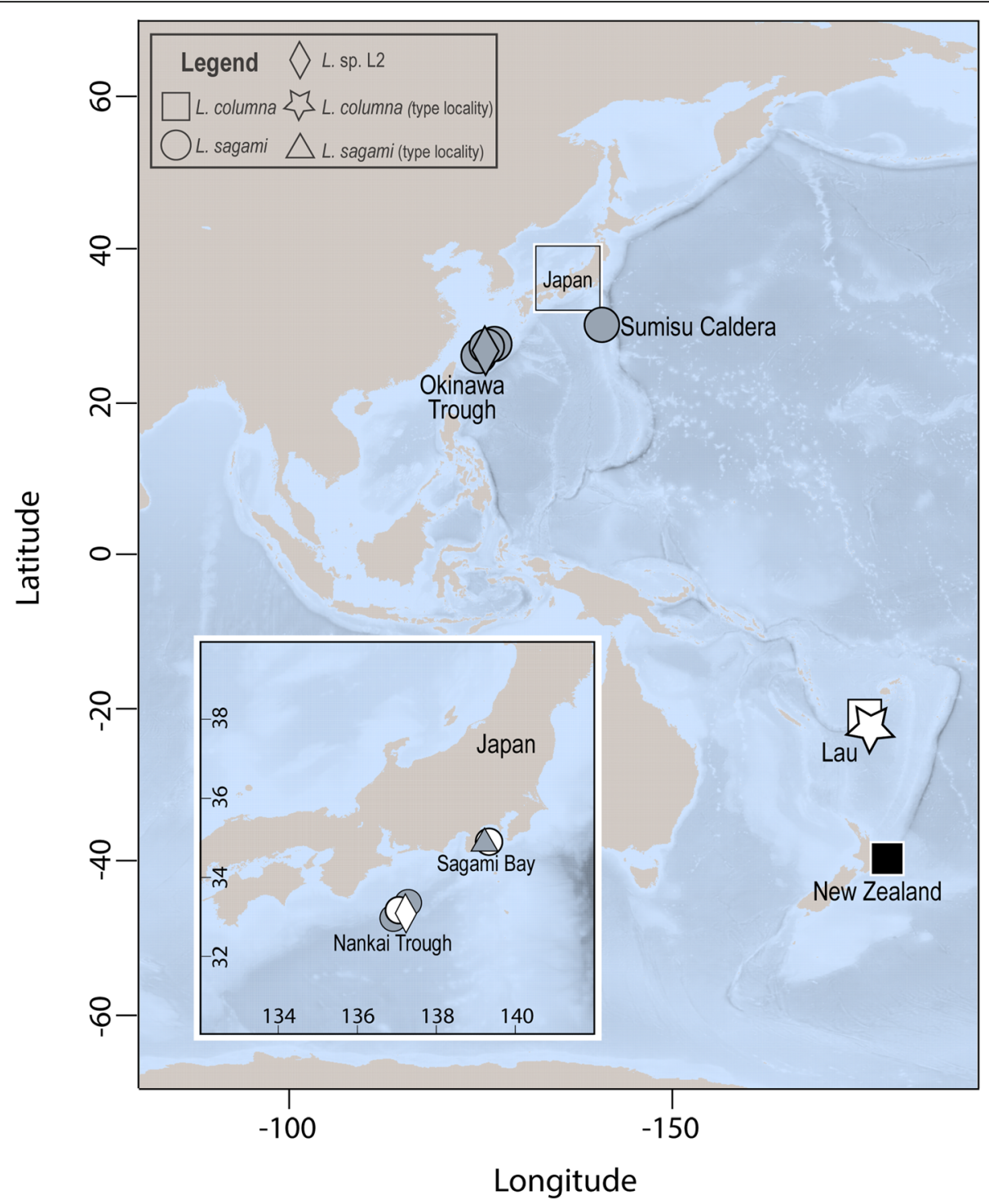

Fig. 1 Distribution of Lamellibrachia columna (Braby et al. 2007; Kojima et al. 2003; Kojima et al. 2001), Lamellibrachia sagami (Kobayashi et al. 2015; Kojima et al. 2003; Kojima et al. 2001), and Lamellibrachia sp. L2 (Kojima et al. 1997; Kojima et al. 2001). Squares represent L. columna localities, circles represent L. sagami localities, and diamonds represent L. sp. L2 localities. Symbols that are white represent localities with supporting molecular data, while symbols that are grey represent localities without molecular data. Black square represents the newly sampled $L$. columna with molecular data from this study. Star and triangle represent type localities for L. columna and L. sagami, respectively

The samples identified as Lamellibrachia sp. L1 in Kojima et al. 2001 were subsequently described as Lamellibrachia sagami Kobayashi et al 2015, with the type locality being a cold seep at $853 \mathrm{~m}$ in Sagami Bay, Japan. Lamellibrachia sagami was differentiated from other Lamellibrachia species by its sheath and branchial lamellae and the sizes of its vestimental and trunk plaques (Kobayashi et al. 2015). It has also been reported from other cold seeps along the eastern coast of Japan (Fig. 1) at depths of 290-2180 m (Kobayashi et al. 2015; Kojima et al. 2015; Kojima et al. 1997; Miura and Fujikura 2008).
Lamellibrachia sagami has been found sympatrically with its close genetic relative L. sp. L2 (Kojima et al. 2001; Kojima et al. 1997) off the east coast of Japan at the Nankai Trough (Kobayashi et al. 2015; Kojima et al. 2003; Kojima et al. 2001; Kojima et al. 1997).

Here we report a new record of Lamellibrachia columna collected from cold seeps of the Hikurangi Margin off New Zealand. Phylogenetic and morphological analyses confirm the identification of specimens collected at this locality as L. columna, thereby extending its range southward by approximately $1900 \mathrm{~km}$. We 
explore other records of closely-related Lamellibrachia species from Japan, and discuss the resulting biogeographical implications for Lamellibrachia columna.

\section{Methods}

Samples (NIWA 27133) were loaned to Scripps Institution of Oceanography by New Zealand's National Institute of Water and Atmospheric Research (NIWA). These samples were from among other samples of unidentified Lamellibrachia specimens originally collected in 2006 from cold seeps off the east coast of the North Island of New Zealand (see Baco et al. 2010 and Bowden et al. 2013 for a full description of the habitat and locations where the tube worms were found, and their densities). The anterior and a portion of the trunk of the specimens examined here for DNA analysis, were originally fixed in $99 \%$ ethanol and later frozen $\left(-20^{\circ} \mathrm{C}\right)$. These three specimens were collected from the Builder's Pencil seep site, between 810 and $817 \mathrm{~m}$ (NIWA 27133A, NIWA 27133B, SIO-BIC A9468). Whole specimens were photographed prior to preservation using a Nikon D70S with $90 \mathrm{~mm}$ Nikkor lens mounted on a fixed copy stand column. Ten plaques from the vestimentum and ten plaques from the trunk of each specimen were measured by cutting thin pieces of epidermis from the vestimentum and trunk and placing them on a glass slide with a $5 \%$ sodium hydroxide solution prior to observation. Analysis of morphological features of whole specimens was completed post-preservation and compared to morphological records of L. columna published by Southward (Southward 1991; Southward et al. 2011).

DNA was extracted from the vestimentum of the New Zealand specimens with the Zymo Research DNATissue Miniprep kit, following the protocol supplied by the manufacturer. Approximately 1275 base pairs (bp) of mitochondrial cytochrome subunit I (COI) were amplified using the vestimentiferan $m t C O I$ primer set COIf and COIr (Nelson and Fisher 2000) and up to $600 \mathrm{bp}$ of $16 \mathrm{~S}$ rRNA (16S) were amplified using the primer set $16 \mathrm{SbrH}$ and 16sArL (Palumbi 1996). Amplification was carried out in a thermal cycler (Eppendorf) with $12.5 \mu \mathrm{L}$ Apex 2.0x RED DNA Polymerase Master Mix (Genesee Scientific), $1 \mu \mathrm{L}$ each of the appropriate forward and reverse primers $(10 \mu \mathrm{M}), 8.5 \mu \mathrm{L}$ water, and $2 \mu \mathrm{L}$ eluted DNA. The vestimentiferan COI temperature profile was as follows: $95^{\circ} \mathrm{C} / 300 \mathrm{~s}-\left(94{ }^{\circ} \mathrm{C} / 60 \mathrm{~s}-55^{\circ} \mathrm{C} / 60 \mathrm{~s}-72{ }^{\circ} \mathrm{C} /\right.$ $120 \mathrm{~s}) * 35$ cycles $-72^{\circ} \mathrm{C} / 420 \mathrm{~s}$. The $16 \mathrm{~S}$ temperature profile was as follows: $95^{\circ} \mathrm{C} / 180 \mathrm{~s}-\left(95^{\circ} \mathrm{C} / 40 \mathrm{~s}-50^{\circ} \mathrm{C} /\right.$ $\left.40 \mathrm{~s}-72^{\circ} \mathrm{C} / 50 \mathrm{~s}\right) * 35$ cycles $-72^{\circ} \mathrm{C} / 300 \mathrm{~s}$. The PCR products were purified with the ExoSAP-IT protocol (USB, Affymetrix), and sequencing was performed by Eurofins Genomics (Louisville, KY).

Alignments of the newly generated sequences and available sequence data from GenBank for COI and $16 \mathrm{~S}$
(Table 1) published in the most recent siboglinid phylogenies (Black et al. 1997; Braby et al. 2007; Cowart et al. 2014; Kobayashi et al. 2015; Kojima et al. 2001; Li et al. 2017; Li et al. 2015; McCowin and Rouse 2018; McMullin et al. 2003; Miglietta et al. 2010; Sun et al. 2018), including sequences for Lamellibrachia columna from the type locality (Lau Back Arc Basin), were performed using MAFFT with default settings (Katoh and Standley 2013) and concatenated with SequenceMatrix v.1.6.7 (Gaurav et al. 2011). For species that showed very little variation in COI (L. anaximandri, L. cf. luymesi, L. satsuma, L. barhami), a single individual was chosen to represent each lineage in the phylogenetic analyses. Lamellibrachia juni also showed little intraspecific variation in COI, but multiple individuals were chosen to represent the lineage for comparison with the other analyses conducted in this study. This species has also been recorded in the closest geographic proximity to the species of Lamellibrachia examined here (i.e., hydrothermal vents of the Kermadec Arc, to the north of New Zealand - 524 $\mathrm{km}$ distant) (Miura and Kojima 2006). Maximum likelihood (ML) analyses were conducted on the concatenated dataset using RAxML v.8.2.19 (Stamatakis 2014) with each partition assigned the GTR + G + I model by the Akaike information criterion (AIC) in jModelTest 2 (Darriba et al. 2012; Guindon and Gascuel 2003). Node support was assessed via a thorough bootstrapping (1000 replicates). Bayesian Inference (BI) analyses were also conducted using MrBayes v.3.2.5 (Ronquist et al. 2012) with the same best-fit models assigned to their respective partitions. Maximum parsimony (MP) analyses were conducted using PAUP* v.4.0a (Swofford 2002), using heuristic searches with the tree-bisection-reconnection branchswapping algorithm and 100 random addition replicates. Support values were determined using 100 bootstrap replicates. Uncorrected pairwise distances were calculated for the COI dataset $(\sim 1275 \mathrm{bp})$ with PAUP* v.4.0a (Swofford 2002). A model-corrected distance analysis for a reduced COI dataset containing the New Zealand specimens (NIWA 27133/SIO-BIC A9468), L. columna, L. sp. L2, and L. sagami (selection supported by all molecular analyses) was also conducted with the best-fit model, HKY (Hasegawa and Kishino 1985), selected via AIC in jModelTest 2. An additional model-corrected distance analysis (best-fit model HKY selected via AIC) was conducted for the $L$. juni COI dataset (all terminals available on GenBank) for comparison with the $L$. columna/L. sp. L2/L. sagami dataset. A haplotype network of the New Zealand specimens, L. columna, L. sp. L2, and L. sagami COI dataset was created with PopART v.1.7 (Bandelt et al. 1999) using the median-joining option and epsilon set at 0 . 
Table 1 Origin of sequenced terminals, vouchers, and GenBank accession numbers. New sequences are set in bold. GM Gulf of Mexico, CR Costa Rica, NZ New Zealand, SP South Pacific

\begin{tabular}{|c|c|c|c|c|}
\hline Scientific Name & Origin & $\mathrm{COI}$ & $16 S$ & Voucher or Reference \\
\hline $\begin{array}{l}\text { Lamellibrachia } \\
\text { anaximandri }\end{array}$ & Eastern Mediterranean & EU046616 & HM746782 & SMH-2007a \\
\hline $\begin{array}{l}\text { Lamellibrachia } \\
\text { barhami }\end{array}$ & Jaco Scar, CR & MH670766-92 & MH660399 & SIO-BIC A8343 \\
\hline $\begin{array}{l}\text { Lamellibrachia } \\
\text { columna }\end{array}$ & Lau Back Arc Basin & U74061 & - & Black et al. 1997 \\
\hline $\begin{array}{l}\text { Lamellibrachia } \\
\text { columna }\end{array}$ & Lau Back Arc Basin & DQ996645 & FJ347646 & $\begin{array}{l}\text { Braby et al. 2007, Vrijenhoek et } \\
\text { al. } 2009\end{array}$ \\
\hline $\begin{array}{l}\text { Lamellibrachia } \\
\text { columna }\end{array}$ & Hikurangi Margin, NZ & MK496532-34 & MK93453-55 & $\begin{array}{l}\text { SIO-BIC A9468, NIWA } \\
\text { 27133A, NIWA 27133B }\end{array}$ \\
\hline Lamellibrachia sp. L2 & Nankai Trough, Japan & D50592 & - & Kojima et al. 1997 \\
\hline $\begin{array}{l}\text { Lamellibrachia } \\
\text { donwalshi sp. nov. }\end{array}$ & Mound $12, \mathrm{CR}$ & MH670827 & MH664918 & SIO-BIC A8382 \\
\hline Lamellibrachia juni 1 & $\begin{array}{l}\text { TOTO Caldera, Mariana } \\
\text { Arc }\end{array}$ & AB264601 & - & Kojima et al. 2006 \\
\hline Lamellibrachia juni 2 & Manus Basin, SP & AB264602 & - & Kojima et al. 2003 \\
\hline Lamellibrachia juni 3 & Manus Basin, SP & AB264603 & - & Kojima et al. 2006 \\
\hline Lamellibrachia juni 4 & $\begin{array}{l}\text { Brothers Caldera, } \\
\text { Kermadec Arc, NZ }\end{array}$ & AB264604 & - & Miura and Kojima 2006 \\
\hline Lamellibrachia juni 7 & Manus Basin, SP & AB088675 & - & Kojima et al. 2003 \\
\hline $\begin{array}{l}\text { Lamellibrachia cf. } \\
\text { luymesi }\end{array}$ & Green Canyon, GM & GU059225 & GU068209 & Miglietta et al. 2010 \\
\hline Lamellibrachia sagami & Sagami Bay, Japan & LC064365 & - & JAMSTEC 1140043315 \\
\hline $\begin{array}{l}\text { Lamellibrachia sagami } \\
\text { (L. sp. L1) }\end{array}$ & Nankai Trough, Japan & D38029 & - & JAMSTEC 1150054786 \\
\hline $\begin{array}{l}\text { Lamellibrachia } \\
\text { satsuma }\end{array}$ & Kagoshima Bay, Japan & KP987801 & KP987801 & Patra et al. 2016 \\
\hline Lamellibrachia sp. 1 & GM & $\begin{array}{l}\text { GU059165-66, GU059169, } \\
\text { GU059227, GU059237 }\end{array}$ & $\begin{array}{l}\text { GU068253-54, GU068257, } \\
\text { GU068212, GU068227 }\end{array}$ & Miglietta et al. 2010 \\
\hline Lamellibrachia sp. 2 & GM & GU059173, GU059175-77 & GU068265, GU068269 & Miglietta et al. 2010 \\
\hline Riftia pachyptila & East Pacific Rise & KJ789166 & KJ789166 & Li et al. 2015 \\
\hline
\end{tabular}

\section{Results}

The ML, BI, and MP analyses (Fig. 2) were congruent, with strong support for the inclusion of the Lamellibrachia specimens from New Zealand within L. columna. An uncorrected pairwise distance analysis and an HKYcorrected distance analysis based on COI sequences showed a maximum distance of $0.50 \%$ between the $L$. columna specimens from the type locality and $L$. columna specimens from New Zealand (Table 2). The haplotype network revealed a two-base-pair divergence between the same samples (Fig. 3). Morphological analyses of the L. columna specimens from New Zealand revealed (Table 3) that all characteristics except the obturaculum and plaque dimensions fell within or near the expected range for L. columna established by Southward 1991. The number of sheath lamellae ranged from 14 to 16 (expected range 8-16 [Southward 1991]), while the number of branchial lamellae ranged from 20 to 22 (expected 21 [Southward 1991]) for each specimen. The obturaculum lengths ranged from 7 to $13 \mathrm{~mm}$ (expected range 15-42 mm [Southward 1991]), while obturaculum widths ranged from 5 to $8 \mathrm{~mm}$ (expected range 8-13 $\mathrm{mm}$ [Southward 1991]). The diameters of the vestimental plaques ranged from 59 to $60 \mu \mathrm{m}$ (expected range 65-90 $\mu \mathrm{m}$ [Southward et al. 2011]), and the diameters of the trunk plaques ranged from 67 to $75 \mu \mathrm{m}$ (expected range $70-120 \mu \mathrm{m}$ [Southward et al. 2011]).

The phylogenetic tree also showed strong support for referring Lamellibrachia sp. L2 as L. columna. There was a maximum uncorrected distance of $0.33 \%$ in COI sequences between the L. columna specimens from the type locality and $L$. sp. L2 (Table 2). In addition, an HKY-corrected distance analysis based on COI sequences showed a maximum distance of $0.5 \%$ between the $L$. sp. L2 specimens from Japan and the specimens from New Zealand. The haplotype network also revealed 


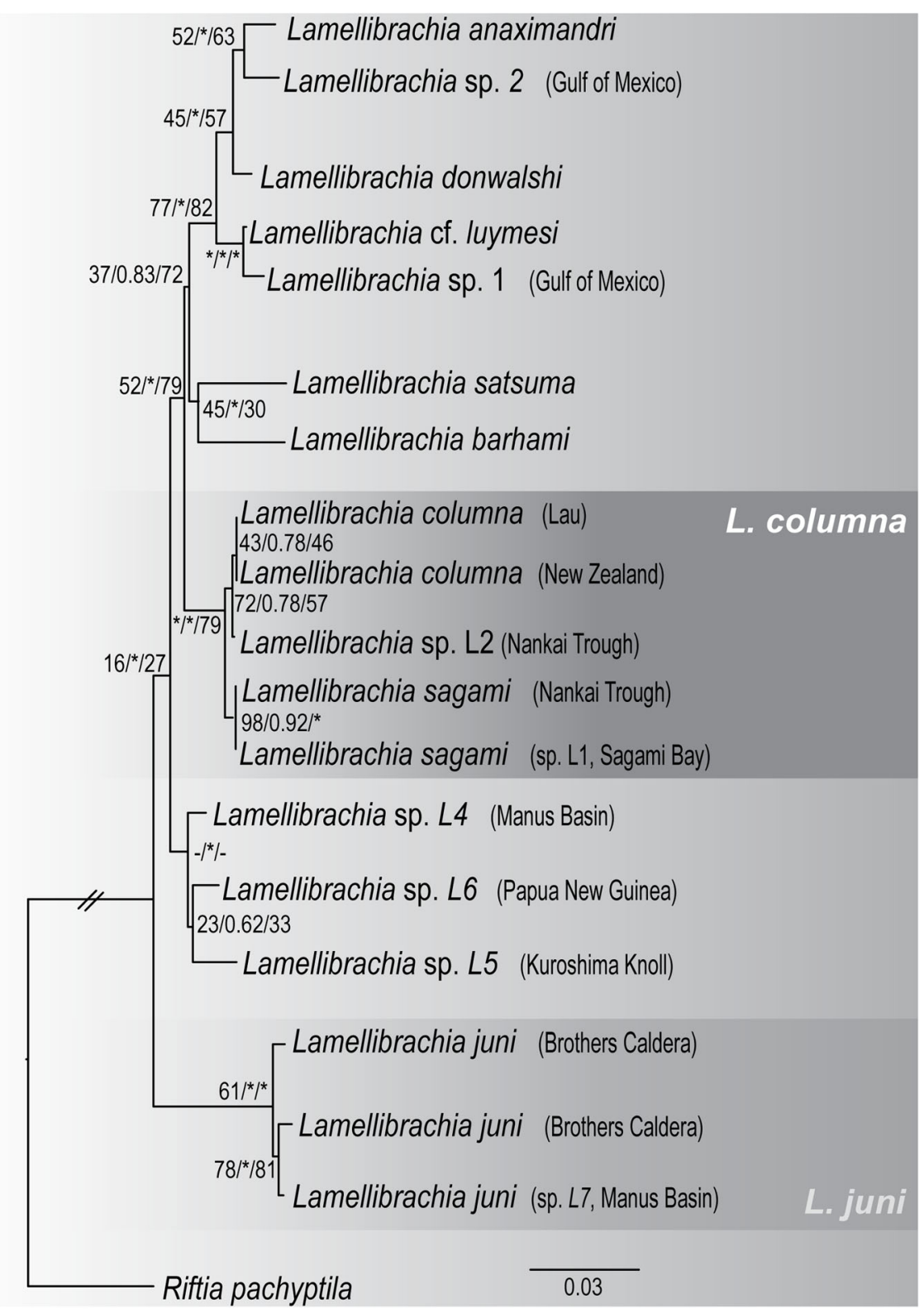

Fig. 2 Maximum likelihood trees of the combined analysis from two mitochondrial genes (16S, COI) aligned with MAFFT and then concatenated (rooted with Riftia pachyptila). Bootstrap support percentages from Maximum Likelihood and Maximum Parsimony analyses (separated by slashes) are followed by Bayesian posterior probabilities. Support values of 95\%/0.95 or greater for each analysis are indicated by asterisks. Nodes not recovered in one of the analyses are indicated by a hyphen

minimal divergence between $L$. sp. L2 and L. columna. Lamellibrachia sp. L2 was found to differ by only two base pairs from L. columna (from the type locality) and shared a haplotype with the New Zealand specimens (Fig. 3).

The phylogenetic tree and both distance analyses also revealed a close relationship between Lamellibrachia columna and L. sagami (Fig. 2, Table 2). Both the uncorrected and corrected analyses based on COI sequences revealed a minimum distance of $0.95-0.98 \%$ between $L$. sagami and the L. columna from the type locality, 0.67$0.69 \%$ between $L$. sagami and the $L$. columna from New Zealand, and $0.64 \%$ between $L$. sagami and the $L$. sp. L2 from Japan. The HKY-corrected analysis showed a maximum distance of $1.35 \%$ between $L$. sagami and $L$. columna from their respective type localities, $0.99 \%$ between $L$. sagami and $L$. sp. L2, and $1.24 \%$ between $L$. sagami and L. columna from New Zealand. An HKYcorrected analysis of L. juni Miura and Kojima, 2006 (Miura and Kojima 2006) generated for comparison 


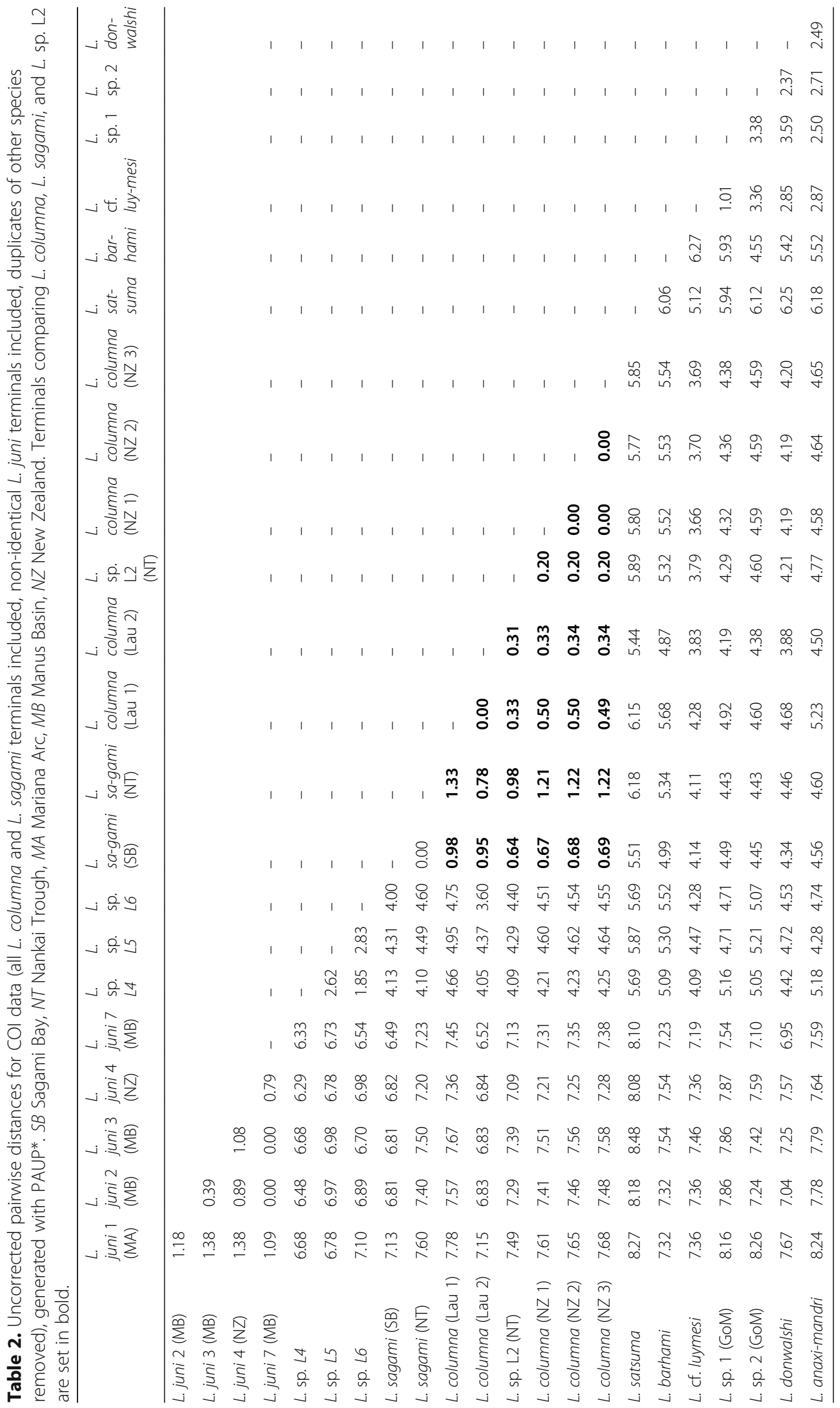




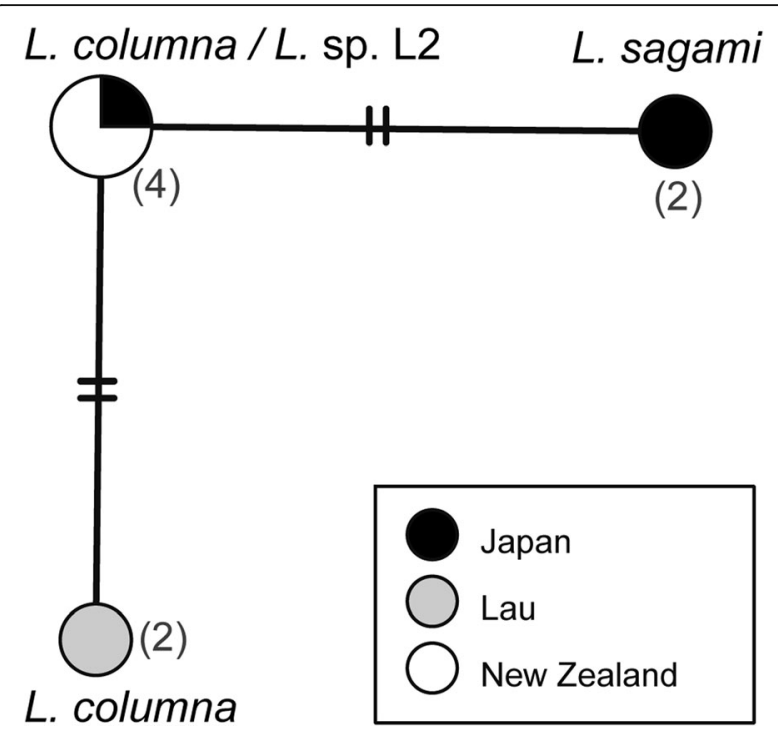

Fig. 3 Haplotype network from COI data for Lamellibrachia columna, L. sp. L2, and Lamellibrachia sagami sampled from New Zealand to Japan. Numbers in parentheses next to each haplotype represent the number of specimens with that haplotype

revealed a maximum distance of $1.39 \%$ among $L$. juni specimens from various localities. The minimum uncorrected COI distance between $L$. juni from the Kermadec Arc, New Zealand and the New Zealand L. columna specimens was $7.28 \%$. Haplotype networks generated for the COI data from L. columna (type locality), the New Zealand specimens, L. sp. L2, and L. sagami (Fig. 3) showed minimal divergence between specimens (at most two base pairs between haplotypes).

The morphological characteristics of Lamellibrachia sagami also fall within or very close to the accepted range for L. columna (Kobayashi et al. 2015; Southward 1991; Southward et al. 2011) and exhibited by the New Zealand $L$. columna specimens, including obturaculum length ( $L$. sagami measures $5.8-22.5 \mathrm{~mm}$ [Kobayashi et al. 2015]), obturaculum width (4.4-10.8 mm [Kobayashi et al. 2015]), number of branchial lamellae (19-26 [Kobayashi et al. 2015]), and vestimental and trunk plaque diameters $(59-101 \mu \mathrm{m}$ and $67-130 \mu \mathrm{m}$, respectively [Kobayashi et al. 2015]), Table 3 . The number of sheath lamellae is the only characteristic that is not partially or completely shared by L. sagami and L. columna (ranges of sheath lamellae reported are 3-6 for $L$. sagami [Kobayashi et al. 2015] and 8-16 for L. columna [Southward 1991]).

\section{Discussion}

All phylogenetic analyses (Figs. 2 and 3) clearly support the inclusion of the specimens collected off New Zealand within Lamellibrachia columna. The minimal base pair differences shown in the haplotype networks (Fig. 3), and the low pairwise distances (corrected and uncorrected) between sequences from L. columna and the New Zealand specimens provide strong support for this result. Morphological measurements of the New Zealand specimens fell within or very close to the accepted ranges for diagnostic characters of $L$. columna (Southward 1991; Southward et al. 2011). This morphological similarity can be seen clearly when comparing specimens from New Zealand and Lau in Table 3 and Fig. 4. However, the measurements made of the obturaculum for the New Zealand specimens do show a slight reduction from the previous ranges recorded for this species of $15-42 \mathrm{~mm}$ length and 8-13 $\mathrm{mm}$ width (Southward 1991; Southward et al. 2011). The New Zealand specimens were below this range (7-13 $\mathrm{mm}$ length, $5-8 \mathrm{~mm}$ width) and also exhibited some variation in number of branchial lamellae, which has not been previously reported for this species. However, phenotypic plasticity is common in other Vestimentifera, such as Ridgeia Jones, 1985 (Southward et al. 1995), and has often been a source of past confusion in differentiation of vestimentiferan species (e.g., Ridgeia piscescae Jones, 1985 and its junior synonym $R$. phaeophiale Jones 1985, which exhibited stark morphological differences but no genetic differentiation [Southward et al. 1995]). Furthermore, Southward et al. (1995) suggested that phenotypic plasticity within vestimentiferan species may be a response to physical variation in their environment, and recounted major variation in tubes and various size measurements of $R$. piscescae with environmental differences (Southward et al. 1995).

Table 3 Morphological characters of Lamellibrachia columna and Lamellibrachia sagami. OL Obturaculum length, OW Obturaculum width, BL Number of branchial lamellae, SL Number of sheath lamellae, VP diameter of vestimental plaques, TP diameter of trunk plaque

\begin{tabular}{lllllllll}
\hline Taxon & $\mathrm{n}$ & $\mathrm{OL}(\mathrm{mm})$ & $\mathrm{OW}(\mathrm{mm})$ & $\mathrm{BL}$ & $\mathrm{SL}$ & $\mathrm{VP}(\mu \mathrm{m})$ & $\mathrm{TP}(\mu \mathrm{m})$ & Reference \\
\hline Lamellibrachia columna & 13 & $15-42$ & $8-13$ & 21 & $8-16$ & $65-90$ & $70-120$ & Southward 1991, Southward et al. 2011 \\
Lamellibrachia columna (New Zealand) & 3 & $7-13$ & $5-8$ & $20-22$ & $14-16$ & $59-60$ & $67-75$ & This study \\
Lamellibrachia sagami (holotype, Sagami Bay) & 1 & 15.7 & 10.5 & 25 & 5 & $67-81$ & $91-102$ & Kobayashi et al. 2015 \\
Lamellibrachia sagami (paratypes, Sagami Bay) & 17 & $5.8-22.5$ & $4.4-10.8$ & $19-26$ & $3-6$ & $59-101$ & $67-130$ & Kobayashi et al. 2015 \\
Lamellibrachia sagami (Nankai Trough) & 1 & 10.2 & 6.8 & 23 & 5 & $58-67$ & $70-104$ & Kobayashi et al. 2015 \\
\hline
\end{tabular}



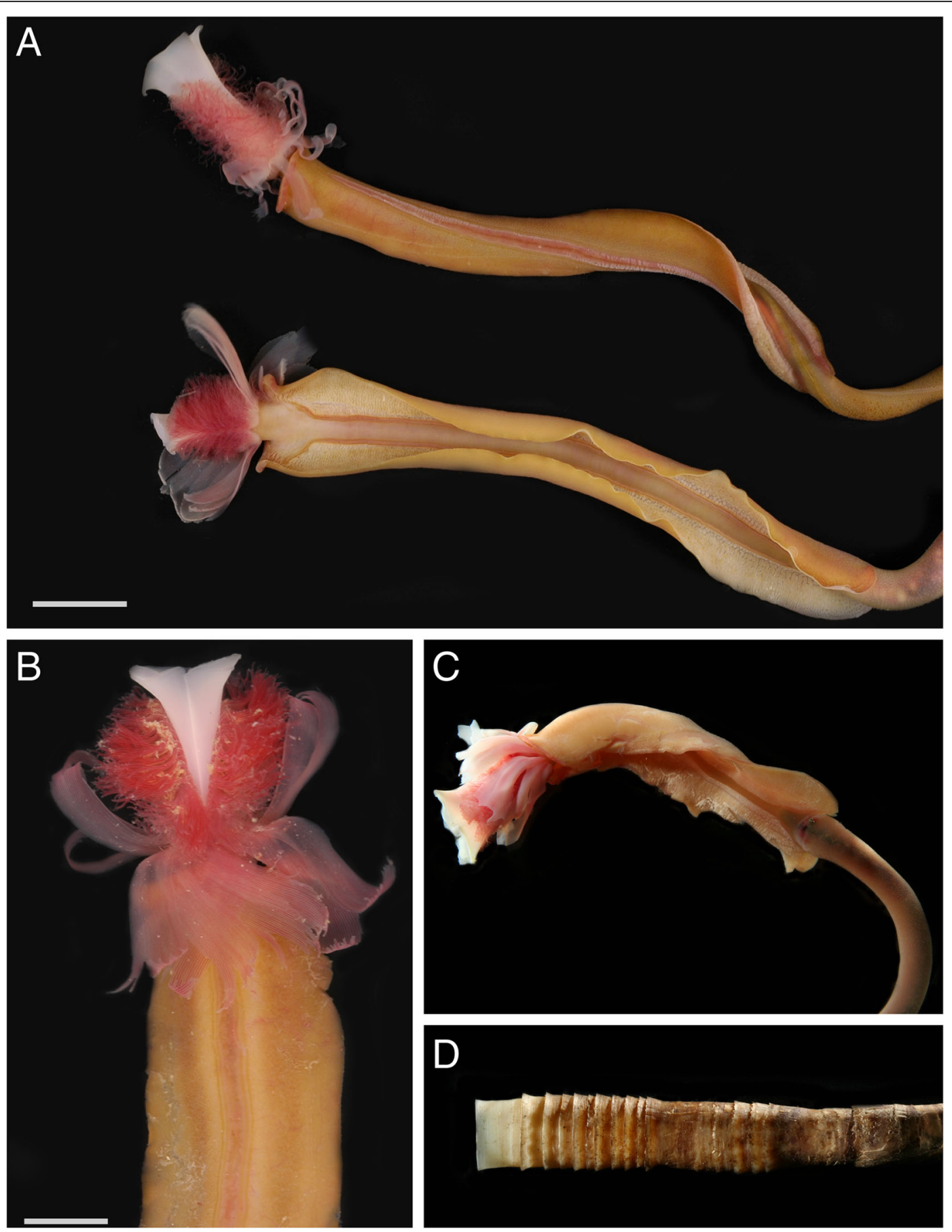

Fig. 4 In situ photographs of Lamellibrachia columna (New Zealand NIWA 27133/SIO-BIC A9468 and Lau specimens). a Ventral (top) and dorsal (bottom) anterior of two L. columna specimens (New Zealand, NIWA 27133/SIO-BIC A9468), scale bar represents $10 \mathrm{~mm}$. b Ventral anterior of L. columna (New Zealand, NIWA 27133/SIO-BIC A9468), scale bar represents 5 mm. c Dorsal anterior of L. columna (Lau [Vrijenhoek et al. 2009]). d L. columna tube anterior (Lau [Vrijenhoek et al. 2009])

Phenotypic plasticity is clearly present within Lamellibrachia as well, as is made apparent by the already wide ranges of morphological characters previously established for various Lamellibrachia species (Gardiner and Hourdez 2003; Jones 1985; Kobayashi et al.
2015; McCowin and Rouse 2018; Miura et al. 1997; Miura and Kojima 2006; Southward 1991; Webb 1969). Thus, a slight widening of the range for a few morphological traits of $L$. columna is not surprising. We therefore designate the New Zealand Lamellibrachia specimens 
as $L$. columna, which will extend the geographic range of $L$. columna southward by approximately $1900 \mathrm{~km}$ and the depth range of $L$. columna by approximately $1000 \mathrm{~m}$ (for a new depth range of 810-1914 m).

All phylogenetic analyses also supported the inclusion of Lamellibrachia sp. L2 within L. columna (Fig. 2). The phylogenetic tree (Fig. 2) shows a very short branch length between $L$. columna and $L$. sp. L2 that is comparable to the branch lengths within $L$. juni (Kojima et al. 2003; Kojima et al. 2001). The haplotype network (Fig. 3 ) and distance analyses (Table 2) also clearly show that there are few genetic differences between L. columna from the type locality and $L$. sp. L2. This similarity has been noted before by Kojima et al. (2001). It was reported in that study that the genetic distance between $L$. columna and $L$. sp. L2 was approximately $0.3 \%$ (Kojima et al. 2001), which is consistent with the uncorrected distances calculated in this study (Table 2). Based on the previously accepted variation within the $L$. juni clade (Kojima et al. 2003; Kojima et al. 2001) represented numerically by the small corrected and uncorrected pairwise distances of up to $1.39 \%$ between $L$. juni specimens from various localities (Table 2), L. sp. L2 should be considered conspecific with L. columna, as it exhibits similarly minute corrected and uncorrected pairwise distances (0.31-0.34\%, Table 2) from L. columna specimens from the type locality. There is no morphological data published for L. sp. L2 (Kojima et al. 2003; Kojima 2002; Kojima et al. 2001), but the molecular evidence overwhelmingly supports the referral of $L$. sp. L2 sequences to L. columna. This will extend the depth range of $L$. columna to $3270 \mathrm{~m}$ (Kojima et al. 2001; Kojima et al. 1997) and its geographic range to southeastern Japan. As a result, $L$. columna will represent the most broadly distributed Lamellibrachia species to date, with a geographic range spanning approximately $9000 \mathrm{~km}$ from the coast of New Zealand to the coast of Japan and a depth range of $810-3270 \mathrm{~m}$. This range extension will also result in the putative geographic sympatry of $L$. columna and $L$. sagami, since both $L$. sp. L2 and $L$. sagami have been sampled from the Nankai Trough (Kobayashi et al. 2015; Kojima et al. 2001).

Our results (Fig. 2), and those previously published (Kojima et al. 2001), showed high support for the close sister relationship between $L$. sagami and $L$. columna/L. sp. L2. This topology is reminiscent of the level of variation within the $L$. juni clade, which has a similar topology, suggesting that the $L$. sagami/L. columna/L. sp. L2 clade should also represent a single species. The uncorrected and corrected pairwise distances between $L$. sagami and L. columna provide additional support for this potential revision. The maximum HKY-corrected distance was $1.35 \%$ between $L$. columna and L. sagami from their respective type localities, $0.99 \%$ between the sympatric $L$. sp. L2 (L. columna) and L. sagami sequences, and $1.24 \%$ between $L$. sagami from Japan and L. columna from New Zealand (all uncorrected distances were smaller, Table 2). The small distances between $L$. columna and $L$. sagami and $L$. sp. L2 (L. columna) recovered in this study have been previously noted, and $L$. sagami (called "L. sp. L1" prior to its formal description in 2015) and $L$. sp. L2 (now L. columna) were reported as potentially "conspecific with L. columna" due to their small genetic distances (0.5-1.1\%) from L. columna (Kojima et al. 2001). Other Lamellibrachia species in Japan and New Zealand that are geographically close to or sympatric with $L$. columna and $L$. sagami, such as $L$. juni and $L$. satsuma, are clearly genetically distinct, with uncorrected distances ranging between 5.44 and $8.48 \%$ (Table 2). The distance between $L$. sagami and $L$. columna is comparable to distances calculated within the single species $L$. juni $(0-1.38 \%$ uncorrected, $0-1.39 \%$ HKY-corrected). The haplotype network (Fig. 3) of $L$. sagami, $L$. columna, and $L$. sp. L2 provides a visual representation of this close relationship (two base-pair distances between haplotypes) which also supports their synonymy. The referral of $L$. sp. L2 to L. columna in this paper also results in the sympatry of $L$. columna and $L$. sagami off the eastern coast of Japan, with records from each at the Nankai Trough (Kobayashi et al. 2015; Kojima et al. 2001, 2003; Southward 1991; Southward et al. 2011). The morphological data also reveals similarities between L. sagami and L. columna. Nearly all of the morphological characters of L. sagami (obturaculum length and width, plaque diameters, branchial lamellae) closely overlap with the ranges accepted for L columna (Kobayashi et al. 2015; Southward 1991; Southward et al. 2011) (Table 3), except for the number of sheath lamellae, which falls in a smaller range for L. sagami (3-6 [Kobayashi et al. 2015]) than for L. columna (8-16 [Southward et al. 2011; Southward 1991]). As was made evident by Southward et al. (Southward et al. 1995), phenotypic plasticity is not uncommon in Vestimentifera and has resulted in past confusion regarding species descriptions based heavily on morphology. The molecular analyses, morphological analyses, and geographic sympatry support the synonymy of $L$. sagami with $L$. columna. Past studies have shown low levels of variation in the mitochondrial genes $16 \mathrm{~S}$ and COI in Vestimentifera (Cowart et al. 2014; Cowart et al. 2013; McMullin et al. 2003), so further genetic data is required to elucidate more detailed patterns of gene flow in widely distributed species like L. columna. However, present evidence, especially the small number of base pair variations and the distance comparison with $L$. juni and other Lamellibrachia species, justifies the synonymy of $L$. sagami with $L$. columna. We synonymize the two here and amend the diagnosis of $L$. columna to include the additional 
morphological variation represented by its junior synonym L. sagami (see below).

Biogeographies of hydrothermal vent fauna indicate that vent fauna of the western Pacific are generally distinct from those of the eastern Pacific (Van Dover et al. 2002; Moalic et al. 2012), but also indicate various levels of latitudinal sub-division among the vent fauna of the western Pacific (Bachraty et al. 2009; Rogers et al. 2012). These sub-divisions presumably represent evolutionary and modern-day processes that influence population connectivity (Mitarai et al. 2016), and while our finding of a high degree of relatedness among Lamellibrachia columna from off Japan and New Zealand does not refute the proposed sub-divisions of the overall vent faunal assemblages of the western Pacific, it provides an interesting example of at least one species of chemosynthetic environments that maintains a population across almost the entire latitudinal range of the region. Our study now confirms that L. columna is found at both vents and cold seep habitats, and that at the southernmost extent of its range off New Zealand it occurs at seeps, but apparently does not occur at vents off New Zealand. It is possible that environmental conditions at vent sites off New Zealand are not suitable for L. columna, where L. juni is found (Miura and Kojima 2006), or that the species is yet to be discovered at these sites. Whatever the reason may be for the apparent lack of L. columna at vents off New Zealand, our finding of the species at seeps is useful in terms of documenting the extent of the habitat flexibility of Lamellibrachia, and for developing a biogeography of cold seep fauna which is much less wellunderstood than for vent fauna.

\section{Taxonomy}

Siboglinidae Caullery, 1914.

Lamellibrachia Webb, 1969.

\section{Lamellibrachia columna Southward, 1991}

Lamellibrachia sp. L1 (Sagami Bay, Nankai Trough): Kojima et al. 1997 (L. sp. La1-4, Lc1-4, Ld1, Ld2-3, Ld4), p. 509; Kojima et al. 2001, p. 211; Kojima 2002, p. 57; Kojima et al. 2003, p. 625; Kojima et al. 2006, p. 1357; Miura and Kojima 2006, p. 209; Miura and Fujikura 2008, p. 57; Miura and Fujikura 2008, p. 153, Fig. 9.3 A-C.

Lamellibrachia sp. L2 (Nankai Trough): Kojima et al. 1997 (L. sp. Le1, Le2), p. 509; Kojima et al. 2001, p. 213; Kojima 2002, p. 346; Kojima et al. 2003, p. 631.

Lamellibrachia sagami new synonym (Sagami Bay): Kobayashi et al. 2015, p. 99. Figs. 2-5.

Material examined: Three specimens were collected from the Builder's Pencil seep site off the east coast of the North Island of New Zealand, between 810 and 817 $\mathrm{m}$, using an epibenthic sled (Station TAN0616/32; 39
32.4' S, $\left.178^{\circ} 20.4^{\prime} \mathrm{W}\right)$. Two of these specimens are deposited at NIWA (NIWA 27133A, NIWA 27133B), and one specimen is deposited at the Scripps Institution of Oceanography Benthic Invertebrates Collection (SIOBIC A9468).

Diagnosis (emended): The obturaculum width ranges from 4.4-13 mm (Kobayashi et al. 2015; Southward 1991 ) and its length ranges from $5.8-42 \mathrm{~mm}$; it is surrounded by the branchial plume $(1,8)$, Fig. $4 \mathrm{a}-\mathrm{c}$. There are 19-26 pairs of branchial lamellae surrounding the obturaculum (Kobayashi et al. 2015; Southward 1991). There are 3-16 pairs of sheath lamellae which enclose the crown region and vary in size but are all shorter than the obturaculum, Fig. 4a-c. The smallest lamellae are near the mid-ventral line (Kobayashi et al. 2015; Southward 1991). The anterior edge of the vestimentum forms a collar with a central split (Kobayashi et al. 2015; Southward 1991). Paired dorsal ciliated genital grooves with epidermal folds occur in males (Fig. 4a, c), while females lack epidermal folds and grooves appear less obvious (Kobayashi et al. 2015; Southward 1991). Tubes are fairly straight and smooth, with an anterior diameter ranging from 14 to $20 \mathrm{~mm}$ (Southward 1991) (Fig. 4d). Vestimental plaques range in diameter from 58 to $101 \mu \mathrm{m}$, while trunk plaques range from 67 to $130 \mu \mathrm{m}$ in diameter.

Distribution: Lamellibrachia columna is known from vents at the Lau Back-arc basin (Black et al. 1997; Braby et al. 2007; Southward 1991), vents and seeps along the middle Honshu coast of Japan (including, but not limited to, the Sagami Bay, Nankai Trough, and Okinawa Trough) (Kobayashi et al. 2015; Kojima et al. 2001; Kojima et al. 1997), and seeps on the Hikurangi margin east of New Zealand, at depths between 270 and $3270 \mathrm{~m}$ (Baco et al. 2010; Black et al. 1997; Bowden et al. 2013; Braby et al. 2007; Kobayashi et al. 2015; Kojima et al. 1997, 2001; Southward 1991).

Remarks: Southward's 1991 diagnosis of Lamellibrachia columna has been amended to accommodate the inclusion of specimens from New Zealand (NIWA 27133, SIO-BIC A9468), Japan (L. sp. L2), and its new junior synonym $L$. sagami. Phylogenetic and morphological evidence suggests that $L$. columna exhibits wider ranges of lamellae counts, plaque diameters, and obturaculum sizes than previously reported.

\footnotetext{
Publisher's Note

Springer Nature remains neutral with regard to jurisdictional claims in published maps and institutional affiliations.
}

\section{Acknowledgements}

We would like to thank Sadie Mills and Caroline Chin (NIWA) for their curation of the samples, and for sending preserved samples to SIO, and David Bowden (NIWA) and Fredrik Pleijel (University of Gothenburg) for providing photographs of L. columna specimens from New Zealand and Lau, respectively. We would also like to thank the crew and scientific party of the RENEWZ I voyage (TAN0616) made using the RN Tangaroa. Amy Baco 
(Florida State University) helpfully provided the results of her preliminary genetic investigation of Lamellibrachia samples from the New Zealand cold seeps

\section{Authors' contributions}

GWR, AR conceived the paper. AR provided specimens from New Zealand, collection data, and input regarding the manuscript. MM performed DNA extraction and amplification and morphological examination of New Zealand specimens, conducted the molecular and phylogenetic analyses, generated the figures and drafted the manuscript. GWR, AR, and MM then finalized the manuscript. All authors read and approved the final manuscript.

\section{Funding}

US National Science Foundation (NSF OCE-1634172); NOAA Ocean Exploration. Grants \#NA05OAR4171076 and \#NA17RJ1231/58; NIWA Science Capability Development Fund projects CRFH073 and CDSB1601.

\section{Availability of data and materials}

Sequence data generated and/or analyzed during this study are available on GenBank (accession numbers provided in Table 1) (Benson et al. 2005).

\section{Ethics approval and consent to participate}

Not applicable.

\section{Consent for publication}

Not applicable.

\section{Competing interests}

The authors declare that they have no competing interests.

\section{Author details}

'Scripps Institution of Oceanography, University of California San Diego, La Jolla, CA, USA. ${ }^{2}$ The National Institute of Water and Atmospheric Research, Wellington, New Zealand.

\section{Received: 8 February 2019 Accepted: 19 May 2019}

Published online: 18 June 2019

\section{References}

Bachraty C, Legendre P, Desbruyères $D$. Biogeographic relationships among deep-sea hydrothermal vent faunas at global scale. Deep Res Part Oceanogr Res Pap. 2009:56:1371-8.

Baco AR, Rowden AA, Levin LA, Smith CR, Bowden DA. Initial characterization of cold seep faunal communities on the New Zealand Hikurangi margin. Mar Geol. 2010;272(1-4):251-9Available from. https://doi.org/10.1016/j.margeo. 2009.06.015.

Bandelt $\mathrm{H}$, Forster $\mathrm{P}$, Röhl A. Median-joining networks for inferring intraspecific phylogenies. Mol Biol Evol. 1999;16(1):37-48.

Benson DA, Karsch-mizrachi I, Lipman DJ, Ostell J, Wheeler DL. GenBank. 2005;33: D34-8.

Black MB, Halanych KM, Maas PAY, Hoeh WR, Hashimoto J, Desbruyères D, et al. Molecular systematics of vestimentiferan tubeworms from hydrothermal vents and cold-water seeps. Mar Biol. 1997;130:141-9.

Bowden DA, Rowden AA, Thurber AR, Baco AR, Levin LA, Smith CR. Cold seep Epifaunal communities on the Hikurangi margin, New Zealand: composition, succession, and vulnerability to human activities. PLoS One. 2013;8(10):20.

Braby CE, Rouse GW, Johnson SB, Jones WJ, Vrijenhoek RC. Bathymetric and temporal variation among Osedax boneworms and associated megafauna on whale-falls in Monterey Bay, California. Deep Res I. 2007;54(10):1773-91.

Bright M, Lallier F. The biology of Vestimentiferan tubeworms. Oceanogr Mar Biol An Annu Rev [Internet]. 2010;48:213-65 Available from: https://doi.org/10. 1201/EBK1439821169-c4.

Caullery M. Sur les Siboglinidae, type nouveau d'invertébrés receuillis par l'expédition du Siboga. C R Hebd Seances Acad Sci. 1914;158:2014-7.

Cowart DA, Halanych KM, Schaeffer SW, Fisher CR. Depth-dependent gene flow in Gulf of Mexico cold seep Lamellibrachia tubeworms (Annelida Siboglinidae). Hydrobiologia. 2014;736:139-54

Cowart DA, Huang C, Arnaud-Haond S, Carney SL, Fisher CR, Schaeffer SW. Restriction to large-scale gene flow vs. regional panmixia among cold seep Escarpia spp. (Polychaeta, Siboglinidae). Mol Ecol. 2013;22:4147-62.
Darriba D, Taboada GL, Doallo R, Posada D. jModelTest 2: more models, new heuristics and parallel computing. Nat Methods. 2012;9(8):772 Available from: http://www.nature.com/articles/nmeth.2109.

Van Dover CL, German CR, Speer KG, Parson LM, Vrijenhoek RC. Evolution and biogeography of Deep-Sea vent and seep invertebrates. Science (80-). 2002; 295(2002):1253-7.

Feldman RA, Shank TM, Black MB, Baco AR, Smith CR, Vrijenhoek RC. Vestimentiferan on a whale fall. Biol Bull. 1998;194(2):116-9 Available from: https://www.jstor.org/stable/1543041.

Gardiner SL, Hourdez S. On the occurrence of the vestimentiferan tube worm Lamellibrachia luymesi van der land and Norrevang, 1975 (Annelida: Pogonophora) in hydrocarbon seep communities in the Gulf of Mexico. Proc Biol Soc Washingt. 2003;116(2):380-94.

Gaurav V, LD J, Rudolf M. SequenceMatrix: concatenation software for the fast assembly of multi-gene datasets with character set and codon information. Cladistics. 2011;27:171-80 Available from: https://onlinelibrary.wiley.com/doi/ abs/10.1111/j.1096-0031.2010.00329.x.

Guindon S, Gascuel O. A simple, fast, and accurate algorithm to estimate large phylogenies by maximum likelihood. Syst Biol. 2003;52(5):696-704.

Hasegawa M, Kishino H. Yano T Aki. Dating of the human-ape splitting by a molecular clock of mitochondrial DNA. J Mol Evol. 1985:22:160-74.

Hilário A, Capa M, Dahlgren TG, Halanych KM, Little CTS, Thornhill DJ, et al. New perspectives on the ecology and evolution of Siboglinid tubeworms. PLoS One. 2011;6(2):14

Jones ML. Riftia pachyptila, new genus, new species, the vestimentiferan worm from the Galápagos rift geothermal vents. Proc Biol Soc Washingt [Internet]. 1980; 93(4):1295-313 Available from: http://www.biodiversitylibrary.org/item/22854.

Jones ML. On the Vestimentifera, new phylum: six new species, and other taxa, from hydrothermal vents and elsewhere. Bull Biol Soc Washingt. 1985;6:117-58.

Katoh K, Standley DM. MAFFT multiple sequence alignment software version 7: improvements in performance and usability. Mol Biol Evol. 2013;30(4):772-80.

Kobayashi G, Miura T, Kojima S. Lamellibrachia sagami sp. Nov., a new vestimentiferan tubeworm (Annelida: Siboglinidae) from Sagami Bay and several sites in the northwestern Pacific Ocean. Zootaxa. 2015;4018(1):97-108.

Kojima S. Deep-sea chemoautosynthesis-based communities in the northwestern Pacific. J Oceanogr. 2002;58(2):343-63.

Kojima S, Ohta S, Yamamoto T, Miura T, Fujiwara Y, Hashimoto J. Molecular taxonomy of vestimentiferans of the western Pacific and their phylogenetic relationship to species of the eastern Pacific. I. Family Lamellibrachiidae. Mar Biol. 2001:139:211-9.

Kojima S, Ohta S, Yamamoto T, Yamaguchi T, Miura T, Fujiwara Y, Fujikura K, Hashimoto J. Molecular taxonomy of vestimentiferans of the western Pacific and their phylogenetic relationship to species of the eastern Pacific III. Alaysia-like vestimentiferans and relationships among families. Mar Biol. 2003; 142:625-35

Kojima S, Segawa R, Hashimoto J, Ohta S. Molecular phylogeny of vestimentiferans collected around Japan, revealed by the nucleotide sequences of mitochondrial DNA. Mar Biol. 1997;127(3):507-13.

Kojima S, Watanabe H, Tsuchida S, Fujikura K, Rowden A, Takai K, et al. Phylogenetic relationships of a tube worm (Lamellibrachia juni) from three hydrothermal vent fields in the South Pacific. J Mar Biol Assoc UK. 2006;86:1357-61 Available from: http://www.journals.cambridge.org/abstract_S002531540601438X.

Levin LA, Orphan VJ, Rouse GW, Rathburn AE, Ussler W, Cook GS, et al. A hydrothermal seep on the Costa Rica margin: middle ground in a continuum of reducing ecosystems. Proc R Soc B Biol Sci [Internet]. 2012;279:2580-8 Available from: http://rspb.royalsocietypublishing.org/cgi/doi/10.1098/rspb.2012.0205.

Li Y, Kocot KM, Schander C, Santos SR, Thornhill DJ, Halanych KM. Mitogenomics reveals phylogeny and repeated motifs in control regions of the deep-sea family Siboglinidae (Annelida). Mol Phylogenet Evol. 2015;85:221-9. https:// doi.org/10.1016/j.ympev.2015.02.008

Li Y, Kocot KM, Whelan NV, Santos SR, Waits DS, Thornhill DJ, et al. Phylogenomics of tubeworms (Siboglinidae, Annelida) and comparative performance of different reconstruction methods. Zool Scr. 2017:46(2):200-13.

McCowin MF, Rouse GW. A new Lamellibrachia species and confirmed range extension for Lamellibrachia barhami (Siboglinidae, Annelida) from Costa Rica methane seeps. Zootaxa. 2018;4504(1):1-22.

McMullin ER, Hourdez S, Schaeffer SW, Fisher CR. Phylogeny and biogeography of deep sea vestimentiferan tubworms and their bacterial symbionts. Symbiosis. 2003;34(1):1-41.

Miglietta MP, Hourdez S, Cowart DA, Schaeffer SW, Fisher C. Species boundaries of Gulf of Mexico vestimentiferans (Polychaeta, Siboglinidae) inferred from 
mitochondrial genes. Deep Res Part II Top Stud Oceanogr. 2010;57:1916-25 https://doi.org/10.1016/.j.dsr2.2010.05.007.

Mitarai S, Watanabe H, Nakajima Y, Shchepetkin AF, McWilliams JC. Quantifying dispersal from hydrothermal vent fields in the western Pacific Ocean. Proc Natl Acad Sci. 2016;113(11):2976-81 Available from: http://www.pnas.org/ lookup/doi/10.1073/pnas.1518395113.

Miura T, Fujikura K. In: Fujikura K, Okutani T, Maruyama T, editors. Deep-sea life-biological observations using research submersibles. Kanagawa: Tokai University Press; 2008

Miura T, Kojima S, editors. Two new species of Vestimentiferan tubeworm (Polychaeta: Siboglinidae a.k.a. Pogonophora) from the Brothers Caldera, Kermadec Arc, South Pacific Ocean. Species Divers. 2006;11(3):209-24 [cited 2018 May 25]; Available from: http://ci.nii.ac.jp/naid/110006794409/en/.

Miura T, Tsukahara J, Hashimoto J. Lamellibrachia satsuma, a new species of vestimentiferan worms (Annelida: Pogonophora) from a shallow hydrothermal vent in Kagoshima Bay, Japan Proc Biol Soc Washingt. 1997; 110(3):447-56 Available from: https://archive.org/details/biostor-81167.

Moalic Y, Desbruyères D, Duarte CM, Rozenfeld AF, Bachraty C, Arnaud-Haond S. Biogeography revisited with network theory: retracing the history of hydrothermal vent communities. Syst Biol. 2012;61(1):127-37.

Nelson K, Fisher CR. Absence of cospeciation in deep-sea vestimentiferan tube worms and their bacterial endosymbionts. Symbiosis. 2000;28:1-15.

Nishijima M, Lindsay DJ, Hata J, Nakamura A, Kasai H, Ise Y, et al. Association of thioautotrophic bacteria with deep-sea sponges. Mar Biotechnol. 2010;12(3): 253-60.

Palumbi SR. Nucleic acid II: the polymerase chain reaction. In: Hillis DM, Moritz C, Mable BK, editors. Mol. Syst. 2nd ed. Sunderland, MA: Sinauer associates, Inc; 1996. p. 205-47.

Patra AK, Kwon YM, Kang SG, Fujiwara Y, Kim SJ. The complete mitochondrial genome sequence of the tubeworm Lamellibrachia satsuma and structural conservation in the mitochondrial genome control regions of order Sabellida. Mar Genomics. 2016;26:63-71. https://doi.org/10.1016/j.margen. 2015.12.010.

Pleijel F, Dahlgren TG, Rouse GW. Progress in systematics: from Siboglinidae to Pogonophora and Vestimentifera and back to Siboglinidae. C R Biol. 2009; 332:140-8 [cited 2018 May 28] Available from: https://www.sciencedirect. com/science/article/pii/S1631069108003004?via\%3Dihub.

Rogers AD, Tyler PA, Connelly DP, Copley JT, James R, Larter RD, et al. The discovery of new deep-sea hydrothermal vent communities in the Southern Ocean and implications for biogeography. PLoS Biol. 2012;10(1):17.

Ronquist F, Teslenko M, van der Mark P, Ayres D, Darling A, Hohna S, et al. Efficient Bayesian phylogenetic inference and model choice across a large model space. Syst Biol. 2012;61:539-42.

Shank TM, Fornari DJ, Von Damm KL, Lilley MD, Haymon RM, Lutz RA. Temporal and spatial patterns of biological community development at nascent deepsea hydrothermal vents (9॰ 50'N, East Pacific rise). Deep Res II. 1998;45:465515.

Southward EC. Three new species of Pogonophora, including two vestimentiferans, from hydrothermal sites in the Lau Back-Arc Basin (Southwest Pacific Ocean). J Nat Hist. 1991;25(4):859-81 [cited 2018 May 27] Available from: http://www.tandfonline.com/doi/abs/10.1080/ 00222939100770571.

Southward EC, Andersen AC, Hourdez S. Lamellibrachia anaximandri n. sp., a new vestimentiferan tubeworm (Annelida) from the Mediterranean, with notes on frenulate tubeworms from the same habitat. Zoosystema. 2011:33(3):245-79 [cited 2018 May 27] Available from: http://www.bioone.org/doi/abs/10.5252/ z2011n3a1.

Southward EC, Tunnicliffe V, Black M. Revision of the species of Ridgeia from Northeast Pacific hydrothermal vents, with a redescription of Ridgeia piscesae Jones (Pogonophora: Obturata = Vestimentifera). Can J Zool. 1995;73(2):28295 Available from: http://www.nrcresearchpress.com/doi/10.1139/z95-033.

Stamatakis A. RAXML version 8: a tool for phylogenetic analysis and post-analysis of large phylogenies. Bioinformatics. 2014;30(9):1312-3.

Sun Y, Liang Q, Sun J, Yang Y, Tao J, Liang J, et al. The mitochondrial genome of the deep-sea tubeworm Paraescarpia echinospica (Siboglinidae, Annelida) and its phylogenetic implications. Mitochondrial DNA Part B Resour. 2018; 3(1):131-2. https://doi.org/10.1080/23802359.2018.1424576.

Swofford DL. Phylogenetic analysis using parsimony (*and other methods). 4th ed. Sunderland: Sinauer Associates, Inc; 2002.

Vrijenhoek RC, Johnson SB, Rouse GW. A remarkable diversity of bone-eating worms (Osedax; Siboglinidae; Annelida). BMC Biol. 2009;7(74):1-13.
Watanabe H, Fujikura K, Kojima S, Miyazaki Jl, Fujiwara Y. Japan: vents and seeps in close proximity. In: Vent seep biota. Top. Geobiol. Vol 33. Dordrecht: Springer; 2010. p. 379-401.

Webb M. Lamellibrachia barhami, gen. Nov., sp. nov. (Pogonophora), from the Northeast Pacific. Bull Mar Sci. 1969;19(1):18-47.

\section{Ready to submit your research? Choose BMC and benefit from:}

- fast, convenient online submission

- thorough peer review by experienced researchers in your field

- rapid publication on acceptance

- support for research data, including large and complex data types

- gold Open Access which fosters wider collaboration and increased citations

- maximum visibility for your research: over $100 \mathrm{M}$ website views per year

At $\mathrm{BMC}$, research is always in progress.

Learn more biomedcentral.com/submissions 